\title{
Rekeang as a Concept of Sustainability in the House of the Society of Karampuang: Redefining Granary
}

\author{
Nita Dwi Estika ${ }^{1}$, Feni Kurniati ${ }^{1}$, Achmad Syaiful Lathif ${ }^{2}$ \\ ${ }^{1}$ School of Architecture, Planning and Policy Development (SAPPD), Insitut Teknologi Bandung, Indonesia \\ ${ }^{2}$ Desain Interior, Fakultas Industri Kreatif, Telkom University, Indonesia \\ fenikurniati@ar.itb.ac.id
}

\begin{abstract}
Whether granaries in traditional communities have survived or being neglected due to modern progress has been widely discussed. However, the discussion remains fragmented and isolated solely on the granary itself, without considering the possibility of its more comprehensive relations. This paper aims to delve into the granary roles in Karampuang, a traditional village in South Sulawesi, to understand how the granary (in the local term 'rekeang') functions and sustains while facing modernization. The inquiry focuses on the interactions between rekeang and farming products, which further results in an understanding of interrelationships between rekeang and its surroundings: 1) domestic spaces, 2) family house units, and 3) with other rekeangs. Each relationship reveals that rekeang has a vital role; besides storing up farming products, it also serves as the key to sustaining the community, especially in cultural and ecological contexts. In the end, the paper proposes a critical insight of 'granary as a network,' which might provide an alternative approach to achieve sustainable development in traditional environments.
\end{abstract}

(C) 2020 IJBESR. All rights reserved.

Keywords: Granary, Karampuang Traditional Village, Network, Rekeang, Sustainable Development

\section{Introduction}

Nowadays, traditional villages' indigenous culture faces modernization that forces old customs such as rice production and rituals to adapt and reposition themselves amid rapid change. Changes, such as technological advances, transform their way of life and shift the traditional process. Cultural transformation occurs as a community's response and effort to create a harmonious situation between old custom and modern life. The transformation process interpretation can be seen from the relationship of people with their place. The transformation itself is a process of discovery through community strategies/solutions to adapt to every new condition and achieve sustainable and truly rooted development. The sensibility is needed to see the root, which is supporting the cultural sustainability of a community. [1]-[5]

Sustainable development is not a goal or destination, but a process of change which contains 'need' and 'making consistent' that is considering the basic human need and their comfortable way of life, besides the ability to adapt to present and future demand [6], [7]. The SDG 2030 agenda promotes culture and environment as the vital role of development and highlights indigenous people's importance [8], [9]. Sustainability is an issue that cannot be separated from ecological/environmental conditions and has the same significance as cultural sustainability. The critical sustainability issues related to vernacular architecture are cultural norms, values, social behavior, and human practice [10], which bears a meaning of continuous dwelling process in 
maintaining a connection to land and place. Current sustainable architecture concerns the effect of human activity on earth. The transformation of buildings is part of continuing the vitality of local culture and reworking the vernacular with respect to the past. [7]

\subsection{Granary in the context of sustainable development}

Farming activity and granary have taken numerous sacred roles in traditional communities, especially in Southeast Asia. In Southeast Asia, rice storage called granary begins by raised floor housing [11]. The granary floor level is higher than the house regarding the rice goddess. Granaries are divided into attic granary and separate granary or within the house [12]. Besides the granary, the closed attic granary serves as a shrine [11]. Nowadays, granaries in traditional buildings have been transformed into houses, with enclosure and openings such as walls, windows, or doors [1].

The traditional community of Karampuang practices farming as their livelihood, and therefore the existence of paddy and granary (in local terms called rekeang) cannot be separated from them. Rekeang was the place to store their 'treasure', crops. Karampuang peoples have traditional folklore entitled I La Galigo that narrates To Manurung as the incarnation of Sang Dewi Padi Sangiangseri (local naming of rice goddess). This folklore is sacralized and is one of the links in their farming life cycle.

In Karampuang, there is a ceremony named Mabbahang as the first step of Mappogau Hanua, which only can be celebrated after paddy in Karampuang village, either traditional or resident rice fields have been harvested [13], [14]. Mappogau Hanua is the most considerable ceremony in Karampuang, with many traditions and rituals that must be held. The Matuli tradition used three rice ties to represent three rice plants (white, black, and red). All of the paddy types used for the ceremony have to be stored and treated well based on their rules and norms [14]. The understanding of granary transformation is identifying the spatial changes of crops in the society, particularly within the domestic spaces where the crops are placed, layover, and stored.

\subsection{The architecture of Karampuang Traditional Community}

The early Karampuang people lived in the mountains, which are strengthened by traces of megalithic civilization like caves, stone gates, possi tanah, emba, customary forest, traditional rice fields, old wells (buhung lohe), and gong stones. There is a hypothesis that the early Karampuang inhabitant lived in a one-story house with a conical roof and developed into a three-pillar conical house, and a square house called Rumah Besar. This change of the stilted square house coincided with Islam's acceptance in Karampuang around the 17th century. The DI / TII incident in 1967 burned the Rumah Besar so that it was rebuilt by maintaining its shape and symbol. Until now, Karampuang peoples still keep and preserve their traditional lifestyle and living centered on the Rumah Besar [15]. There are two types of Rumah Besar, named Rumah Besar of Puang Tomatoa and Rumah Besar of Puang Gella as the traditional leader, which in Rumah Besar of Puang Tomatoa also dwells Puang Guru and Puang Sanro. Rumah Besar is the mother of the other domestic houses of Karampuang's people called bola.

There is a strong conjecture that before the 1980s, the Karampuang people lived in scattered forests and formed a community centered on Rumah Besar. After the 1980s road development, the villagers moved down and built houses along or towards the road. This house is known as bola. The bola architecture is an embodied dwelling culture transformation from the house of society concept at Rumah Besar into dwelling culture that spread into more spreading houses. 
1.3. Granary in Karampuang house of society (Rumah Besar)

The typology of Rumah Besar is a mountain Bugis type with a closed and inward-oriented space. Every Rumah Besar has a granary that spiritually acts as an object and prays for in traditional ceremonies. In the Karampuang's house of society culture, rekeang is located in a closed and dark attic, which can be reached through the kitchen from a wooden ladder. The harvested farming products from traditional rice fields and plantations were submitted to Rumah Besar for traditional ceremonies [16], and stored in rekeang (see Figure 1).

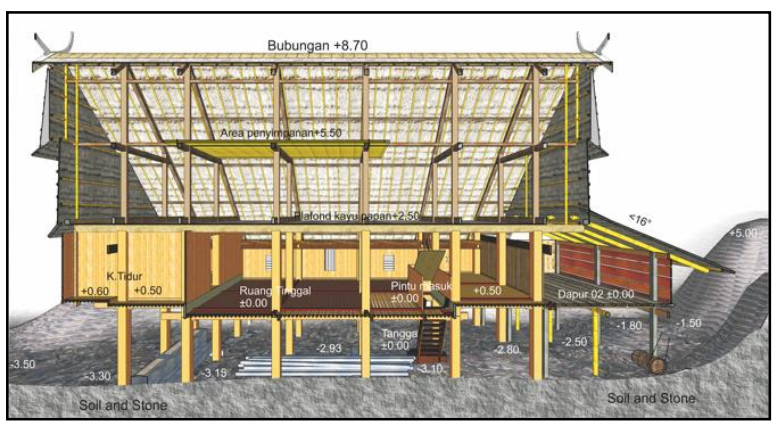

Source: (Magister Teknik Arsitektur Unhas, 2013)

Figure 1: Section of Puang Gella house of society with rekeang on the rooftop

\subsection{Granary in Karampuang domestic houses (Bola)}

Rekeang in bola is located in the attic with more secure access from outside. The bola's rekeang is brighter than rekeang in Rumah Besar because there is usually a skylight inside it. Every bola usually has two rekeang that can be accessed from the bedroom and kitchen. Rekeang reached through a ladder from wood or bamboo. Most of the rekeang still function as a granary, but the others have changed their function to only tool storage. As granary, the stored product in rekeang is usually the harvested farming product from the arable land. It is kept by tying it up or put in a sack (see Figure 2).

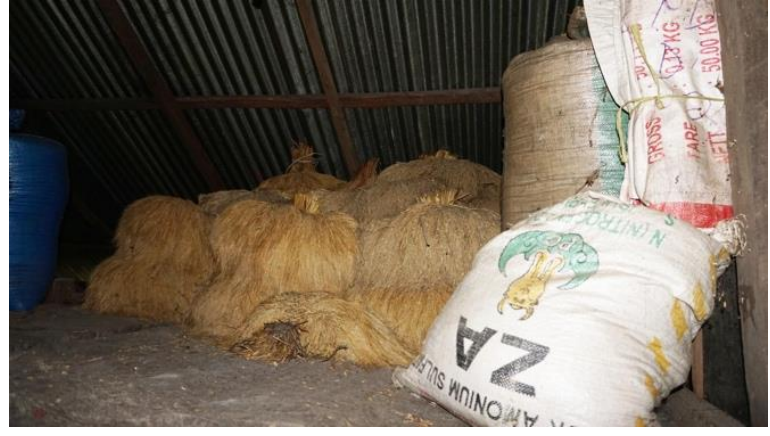

Source: (Author, 2018)

Figure 2: Rekeang in domestic houses (bola)

Rekeang, which is accessed from the bedroom, seems more sacred because of its accessibility and location near the posi bola (the first pillar of the house). It is usually for storing more long term food. On the other hand, there is also a rekeang that is accessed from the kitchen to store daily food.

Farming is still vital in the economy and is symbolic for the community in Karampuang. There is a need to investigate further the existence of rekeang beyond the physical entities' perspective because there is still a lack of study about it. This paper aims to delve into the relationship between the vernacular community's rekeang and farming products in traditional village Karampuang to uncover how sustainability can be achieved from the conventional way of life.

\section{Material and Methods}

Karampuang Traditional Village is located in Bulupoddo District, Sinjai Regency, South Sulawesi. The people living there are peasants and still do their hereditary ritual. This study is exploratory using qualitative-exploratory methods [18], and based on a case study approach of the community about the transformation of their life [19]. The study focuses on farming products and rekeang relations within their domestic, cultural, and symbolic settings. 


\subsection{Collecting data method}

The data were collected through field study and interviews. The field study was conducted twice: the first was in July 2018, and the second was done between 29th October - 1st November 2018 in Mappagau Sihanua and Mubali Sumange (Karampuang's annual traditional ceremony). The interview subjects were the Karampuang's key figures called Ade' Eppa'e, including Puang Amatoa, Puang Gella, Puang Sanro, and Puang Guru. Another interview subject is Puang Juhe, Puang Sitiara, Puang Murni, Puang Asiah, and Puang Samintang as the bola's owner. By experiencing and observing the everyday life of the Karampuang community, including their cultural fest, the analysis/discussion will delve further into relationships that have been established by paddy/farming products.

\subsection{Analysis method}

The collected data is then analyzed through description, interpretation, and the correlation between elements found. The analysis and discussion are divided into three parts to see the relationship between rekeang and its surroundings. Understanding the spatial reconfiguration of farming product placement within domestic spaces might provide critical insights for spatial transformation based on domestic farming activities/paradigm in traditional domestic areas.

\section{Results and Discussions}

As an agricultural community, Karampuang has practiced paddy farming for years, passed down through generations. Farming thus has become the primary occupation for the community in fulfilling their daily needs. Their agricultural livelihood has also formed their built environment with one of its characteristics: an attached granary to the houses, namely 'rekeang'. Rekeang is considered sacred, which can be seen from its position in the house attic. It also becomes rice (paddy) storage that is only put into or removed on special days such as Марроgаи Напиа, like most agricultural societies in Southeast Asian regions that treat granary with the greatest reverence [12].

The incoming modernization that immerses Karampuang village can be seen from the increasing use of modern products and electric households like TV, refrigerator, rice cooker, motorbike, car, etc. (see Figure $3 \& 4$ ), as well as another job for livelihood. Farming and agriculture have become less favorable as a preference. Although such social and technological transformations are perceived as a kind of development [20], many scholars have claimed this as cultural degradations concerning the decrease of granary and farming activities.
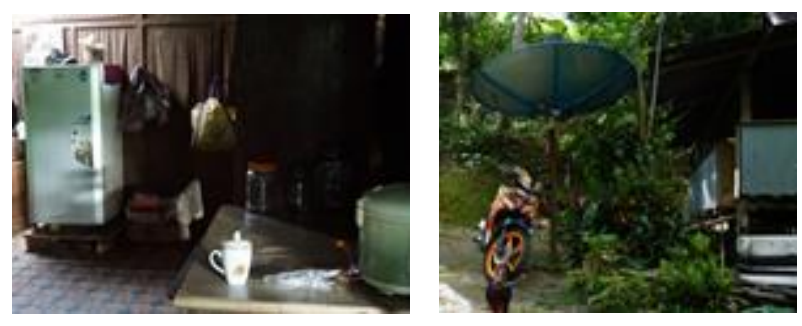

Source: (Author, 2018)

Figure 3 \& 4: Bola with modern products (electricity and motorbike)

Despite these claims, Karampuang benefits from modern life while at the same time maintaining their culture by practicing the kinship systems and annual cultural ceremony. This continuous tradition keeps relation to rekeang and has a role key in achieving cultural and ecological sustainability. Discovering the concept by taking a broader perspective towards granary should be taken because granary (rekeang) is more than just physical entities. It should be mapped with its interrelationships with the surroundings. This paper proposes an approach in looking at relations of paddy and various spaces in Karampuang community, ranging from sacred 
space of symbolic setting, domestic spaces within a housing unit (bola), and cultural space of their kinship system.

\subsection{Rekeang with domestic spaces}

Initially, rekeang served as a sacred place to store paddy rice as rice was associated with the female goddess and fertility representation. The sacredness also could be traced through the way of rice being treated, which would only be removed for the sacred occasions. The position of rekeang, which is at the highest level of the house (attic), also symbolizes the holy world, compared to the middle part of the house (human world) and the ground as a representation of the most profane world. The vertical order of spaces in the house (bola) has illustrated the sacredness degree and defines the importance of each space's goods.

The change that has taken place in the community's everyday life has gradually transformed spatial order. One particular aspect that best describes this transformation is how the paddy or rice storage is reorganized and placed throughout the house's vertical and horizontal spaces. Vertically, rooms are connected through the wooden ladder: from the ground to the main house, and then to the attic or rekeang (see Figure 5). The coming of modernization makes people consider the practicality and functionality of what they always do. So, Karampuang people have reorganized the rice sack, not in vertical order but horizontal order. They place and divide it up from the front of bola (veranda) to the living room and even into the bedroom (as the most private place in the house). Thus, in their everyday lives, Karampuang people do not act rekeang as granary anymore because of its difficulty.

Another concept of spatial arrangement emerging from the reorganization of paddy in the bola is temporality. This transformation is seen through domestic household activity: cooking. The rice sacks for daily meals cook will be temporarily placed near the hearth (kitchen). So the house resident can access it more convenient and accessible than if it is stored in the rekeang.

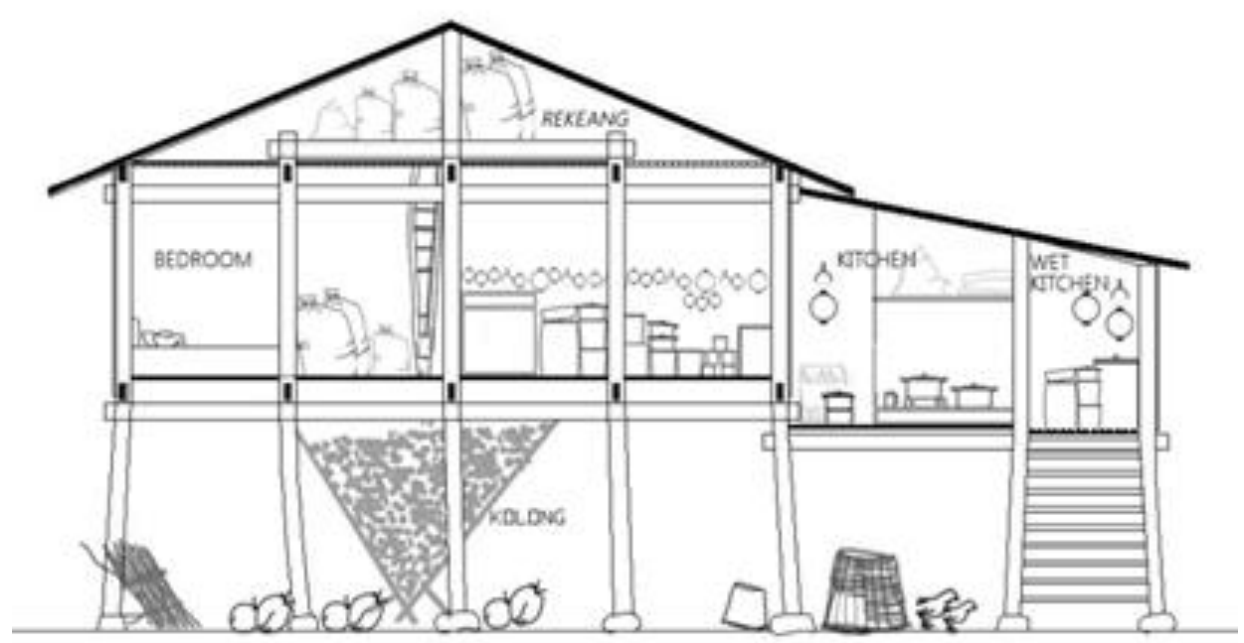

Source: (Author, 2020)

Figure 5: Section of Karampuang domestic house (bola) 
Meanwhile, those stored for seasonal stock and annual festivals are placed relatively far from the kitchen yet conveniently accessible. They are reorganized in very temporary places such as the corner of the bedroom, behind doors, or a divider between bedroom and kitchen (see Figure 5). Therefore, this kind of rice sacks placement pattern informs that horizontal space order awareness has strengthened over the vertical. It shows that horizontal order can be functional complementary towards verticallyordered spaces.

Through vertical spaces in bola, Karampuang people practice an ecologically friendly system in their household and benefit from it. They position the kitchen, with the bamboo floor (which allows waste food and paddy beans going through the slits), right above the chicken coop, while their firewoods are placed under the living room due to its dryness. Thus, the vertical order of spaces in bola has demonstrated an ecologically sustainable system from their ancestral wisdom. Simultaneously, it adopts modern principles through practical and functional aspects of space usage in horizontal orders.

\subsection{Rekeangs with family house units}

Based on the observations, it was found that bola in Karampuang has undergone various architectural transformations, namely 1) the original/Bugis's highland type (which is found dominant in the neighborhood), 2) the emerging bola, 3) the wooden-stoned bola, and 4) the stoned bola. This classification is based on the degree of its physical and functional transformations.

Type one adopts the characteristics of Bugis's highland bola, particularly the veranda (legoh). The use of the ground (kolong) is different. In Bugis (see Figure 6), it is used for fisherman communal space, while in Karampuang, it mainly facilitates the farmer's domestic activities and sometimes for the carpenter (see
Figure 7). However, rekeang in both types is similar, and thus it is considered as type one.
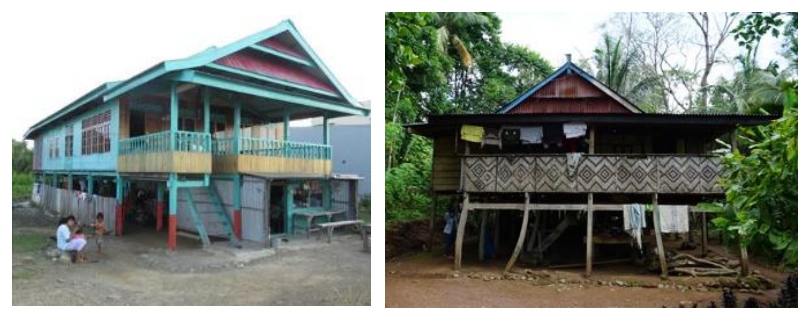

Source: (Author, 2018)

Figure 6 \& 7: Bola of Sinjai \& Bola of Karampuang

Type two, the emerging bola, is the type in which two bolas (the older one, 'the mother' and the younger one, 'the child', emerge into one. This type can be seen in the case of Puang Samintang's bola (see Figure 8). The emerging bola is formed by connecting two bolas from the inside and uniting both into one larger bola, with a sloping roof to cover the two related areas. Every bola has access from the outside; however, in welcoming guests, the 'child' bola is more welcome than the' mother'. Moreover, although the two have emerged into one, each bola maintains its rekeang and relatively functions it as usual, like for food storage.

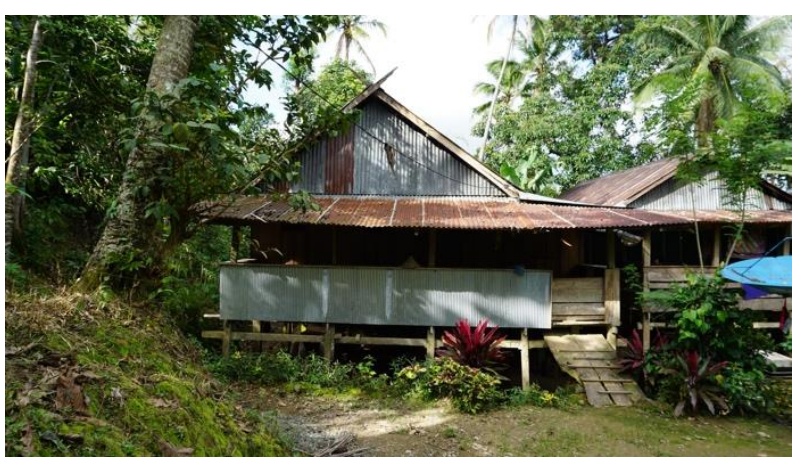

Source: (Author, 2018)

Figure 8: The merging of bola of Puang Samintang's

Type three, the wooden-stone bola is an extension of the wooden bola, the main house. Generally, the stone bola is built beside and attached to the wooden bola, with brickconcrete/stone structures. This case can be seen in Puang Murni's bola consists of two masses/units; the first is a wooden bola on stilts, 
and the second is a stone bola with no rekeang (see Figure 9). The dominant activity in stone bola, is to welcome guests and serve inhabitants in resting, whereas wooden bola functions as a place for cooking and storing food. This phenomenon shows that there has been a function shift from wooden bola into the house of food, although the spaces still function the same. Generally, this stoned bola (child's house) is an extension house, functionally attaches to the wooden bola (mother's house).

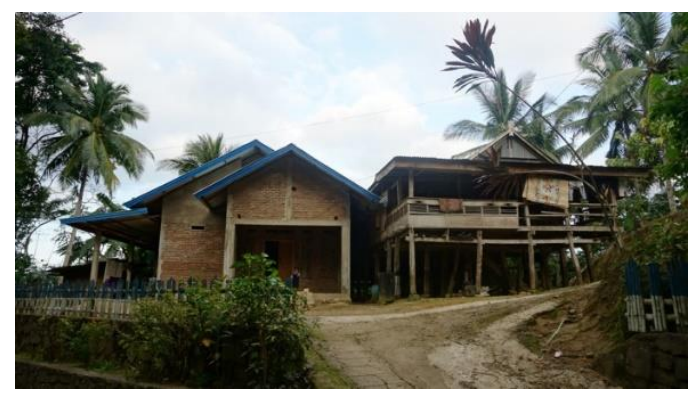

Source: (Author, 2018)

Figure 9: The wooden-stone bola of Puang Murni's

The last type is stoned-wall type bola, which is different from others because it adopts modern architecture from the character of its dominant material, concrete. This stone bola shows the architecture of construction using brick and cement obtained from outside the community. This type widely exists outside the Karampuang village gate, although some can be found within the defined area of Karampuang village (see Figure 10).

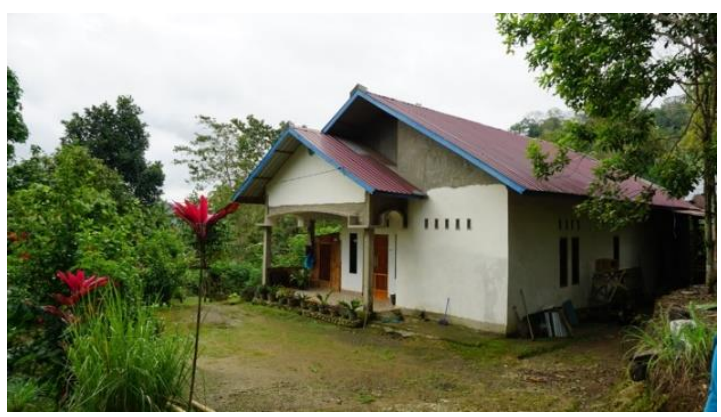

Source: (Author, 2018)

Figure 10: The stone tread bola of Puang Gella's
The four types of bola transformation in Karampuang and how rekeang adjusts to those changes have indicated that the transformation pattern mainly undergoes two processes: merging and extending. The vital highlight from this discussion is that despite the bola transformation, it still preserves its relation with the 'mother' bola and rekeang. This pattern also applies to the relationship between the Rumah Besar and the bola. Rumah Besar is the representation of the parent house of jiji (community group), and the bola is a representation of the children's house. Thus, regardless of those transformations, rekeang still plays a vital role in achieving bola architecture sustainability in Karampuang.

\subsection{Rekeangs with other rekeangs}

The entanglement of networks between rekeangs is formed by how Ade' Eppa'e relation (that is also manifested through the Poto Nabi symbol in Rumah Besar) is carried on Karampuang's rice fields. Ade' Eppa'e is the leadership structure of the Karampuang indigenous people. Rice fields in Karampuang are divided into four types:

a. Galung Arajang: rice fields belong to Arung, also known as akkinanrena arungnge (food source for Arung needs).

b. Galung Abungerreng/Accapengngeng: rice fields for poor people, people affected by a disaster, or indebted people.

c. Galung Hara-hara: rice fields belong to Arung's families and other cultural officials like Gella, Sanro, and Guru.

d. Individual rice fields belong to an individual who is still Karampuang residents.

Rice fields, besides individuals owned, are intended for the public interest. Karampuang holds a norm that is based on togetherness and maintains everything in balance as their basic principle. From network theory, we can see that there is a relationship between rekeangs in 
Karampuang. The relation is formed through their agricultural customs:

a. When there are guests who come to the village, there will be a sign laid out in their sacred wells. People who see it will know that there is a guest in Karampuang, then they are obliged to bring whatever food in their home to Rumah Besar to make food for the guest.

b. In the harvest season, every people in Karampuang helps to harvest paddies from the fields.

c. Rice yields that are collected in Rumah Besar are then distributed to every house by Sanro herself.

d. The distributed rice in every house besides for daily needs is also being used to make a rite (which can be concluded as harvest or new year ritual) in every house.

These customs create a network between rekeang indirectly, and by using these networks, they maintain a system that can hold their natural-built environment ecosystem more resilient. The existing network of rekeang from agriculture activities can be seen in Figure 13 and Figure 14.
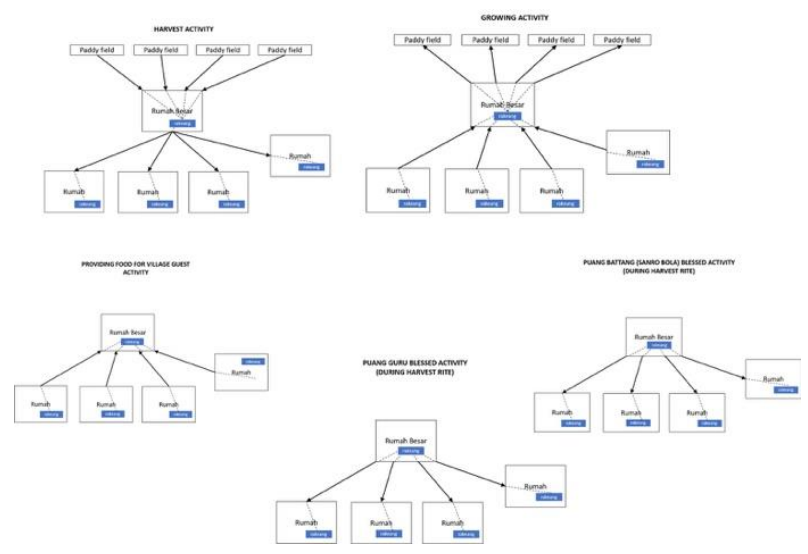

Source: (Author, 2020)

Figure 11: Network diagram from every activity that is happening in Karampuang's agriculture custom

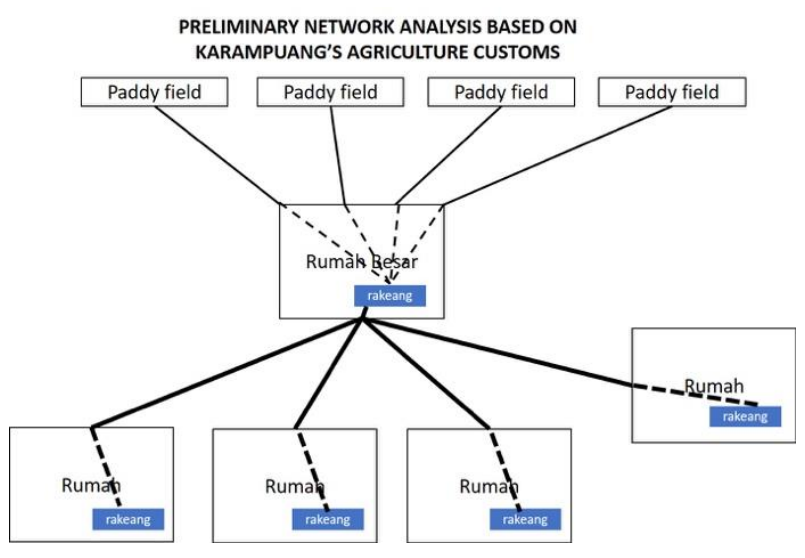

Source: (Author, 2020)

Figure 12: Network analysis in Karampuang's agriculture customs

The network analysis reflects that rekeang plays a vital element in maintaining the network besides Ade' Eppa'e officials. The diagrams also show us how Ade' Eppa'e operates in Karampuang through agricultural customs. This principle is in line with the statement that land is not viewed as a commodity for most indigenous people but rather a sustained endowment with sacred meaning that defines their existence and identity [21]. Thus, upon everything on the land, there is always an ascribed value that interconnects everything in the world. By using this kind of understanding, Karampuang's people keep their settlement sustainable.

\section{Conclusion}

Rekeang plays a vital role in the cultural and ecological sustainability of the Karampuang community. Although modernization changes and adapts their living, rekeang in bola remains. The behavior of storing the crops changes from the vertical orientation to horizontal order. This storing activity is more temporary and functional than symbolic. The rekeang encounters the transformation, but the rekeang still sustains as an essential part of bola as the symbol and power. 
The transformation of bola as the product of adaptation establishes four types of bola. This transformation happens in various ways, like merging, extension, and using modern material. Each type points out how bola branch out but still connect to their house of society. The relation between rekeang from the house of society and the children's house ('bola') is the key to preserve bola architecture's sustainability in Karampuang traditional community.

The traditional ceremony that is practiced in Karampuang emphasizes the high symbolic value of paddy/rice. The preservation of ceremony tradition sustains the granary. Paddy/rice becomes the manifestation of a network between Ade' Eppa'e and the ordinary inhabitant in Karampuang. It is maintained by rekeang presence. So it is essential to keep this kind of relationship system or function to sustain Karampuang community. Furthermore, the house of society concept (Rumah Besar) needs to be redefined. There is a conjecture that bola can also play the role as Rumah Besar, significantly when the settlement expands because of the next generations.

\section{Acknowledgment}

This paper is a part of the research grant awarded by ITB under P3MI KK STKA 2018.

\section{References}

[1] Hanan H. Tradition and Modernization in Indonesian Vernacular Houses, in Southeast Asian Houses: Expanding Tradition. (Editor: Seo RJ). Sepul, The Republic of Korea: Seoul Selection; 2017.

[2] Hanan H. Individual Practice and Cultural Context in the Transformation of Batak Toba House. Asian J. Environ. Stud. 2018;3(7):99-108. doi: 10.21834/ajebs.v3i7.272.

[3] Widiastuti I, Kurniati F. Modernization and vernacularity in the tradition of Minangkabau architecture of the West Sumatra in Indonesia. ISVS Ejournal 2019;6(2):22-31.

[4] Servaes J. Introduction: From MDGs to SDGs. Sustainable Development Goals in the Asian Context. Pp. 1-21. Singapore: Springer Nature; 2017.
[5] AlSayyad N. The End of Tradition, or the Tradition of Endings?, in The End of Tradition? Pp. 1-28. (Editor: AlSayyad). London, United Kingdom: Routledge Taylor \& Francis Group; 2004.

[6] Brandon PS, Lombardi P. Evaluating Sustainable Development in the Built Environment. (2nd ed). Chichester, United Kingdom: John Wiley \& Sons, Ltd; 2011.

[7] Williamson T, Radford A, Bennetts $\mathrm{H}$. Understanding Sustainable Architecture. London, United Kingdom: Spon Press; 2003.

[8] Booth N. Foreword, in Sustainable Development Goals in the Asian Context. (Editor: Servaes J). Singapore: Springer Nature; 2017.

[9] Le Duc A. Religious Environmentalism and Environmental Sustainability in Asia, in Sustainable Development Goals in the Asian Context, (Editor: Servaes J). Singapore: Springer Nature; 2017.

[10] Vellinga M. Vernacular architecture and sustainability: Two or three lessons..., in Vernacular Architecture: Towards a Sustainable Future. Pp. 3-8. 2015.

[11] Domenig G. Consequences of functional change: granaries, granary-dwellings, and houses of the Toba Batak, in Indonesian houses: tradition and transformation in vernacular architecture. Singapore: Singapore University Press; 2004.

[12] Waterson R. The living house: an anthropology of architecture in South-East Asia. Singapore: Oxford University Press; 1990.

[13] Asis A. Nilai Budaya dalam Upacara Adat Mappogau Hanua di Karampuang, Kabupaten Sinjai, Provinsi Sulawesi Selatan. Walasuji 2015;6:381-396. doi: 10.1017/CBO9781107415324.004.

[14] Nasrullah A. Tradisi Upacara Adat Mappogau Hanua Karampuang di Kabupaten Sinjai (Studi Kebudayaan Islam. Universitas Islam Negeri Alauddin Makassar; 2016.

[15] Mithen O, Sampebua, Sunardi, Dirawan GD. Model local wisdom to preserve the environment in South Sulawesi and West Sulawesi Indonesia. Man India 2015;95(4):1041-1050.

[16] Hafid A. Sistem Kepemimpinan pada Komunitas Adat Karampuang di Kabupaten Sinjai. $W a$ 2014;5(1):77-91.

[17] Magister Teknik Arsitektur Unhas. Laporan Arsitektur Vernakular Rumah Adat Karampuang. Makassar, Indonesia; 2013.

[18] Creswell JW. Research design: qualitative, quantitative, and mixed methods approaches. California, United States: Sage Publications, Inc; 2008.

[19] Neuman WL. Social Research Methods: Qualitative and Quantitative Approaches. London, United Kingdom: Pearson Education Limited; 2014.

[20] Wiryomartono B. The politics of development in Indonesia: The aesthetic culture and power play in architecture and urban design. Int. J. Urb. Sci. 
International Journal of Built Environment and Scientific Research

Volume 04 Number 02 | December 2020 p-issn: 2581-1347 | e-issn: 2580-2607 | Pg. 137 - 146

2012;16(2):203-223.

doi:

10.1080/12265934.2012.701442.

[21] Mathur HM. Tribal Land Issues in India: Communal Management, Rights, and Displacement, in Land and

Cultural Survival: The Communal Land Rights of Indigeneous Peoples in Asia. (Editor: Perera J). Pp. 165192. Metro Manila, The Phillipines: Asian Development Bank; 2009. 